\title{
Redactioneel
}

\section{Bewustwording is het begin van verandering}

\author{
Mr. D.C. Houtzager*
}

Tijdens het schrijven van deze bijdrage is de Week van de Toegankelijkheid 2019 in volle gang. Ieder jaar in oktober worden op veel plaatsen in het land activiteiten georganiseerd om aandacht te vragen voor toegankelijkheid. Dit jaar is het thema 'vrije tijd en recreatie'. Dat er nog veel moet gebeuren om de vrijetijdssector inclusief en toegankelijk te maken is wel een cliché. Maar het is juist goed om te kijken naar wat er wel verbetert. Er lijkt een toename van bewustwording te zijn over de noodzaak en de aard van anpassingen. De tijd is wel voorbij dat een instelling kon zeggen 'we zijn toegankelijk' na het aanbrengen van een angepast toilet. Veel musea bijvoorbeeld zorgen niet alleen voor een toegankelijk gebouw, maar ook voor toegankelijkheid van de kunst. Zo kunnen blinde bezoekers van het Eindhovense Van Abbemuseum op bepaalde momenten een kunstwerk voelen of mensen die weinig prikkels kunnen verdragen kunnen een rustige rondleiding krijgen. Stichting De Zonnebloem stuurt mystery guests met een beperking op pad om vrijetijdslocaties te bezoeken en biedt vervolgens ondersteuning aan bij het verbeteren van de toegankelijkheid. In Noord-Brabant zorgt de provincie samen met ondernemers voor de aanleg van toegankelijke natuurpaden.

Bewustwording is het begin van verandering. Dat hebben de opstellers van het $\mathrm{VN}$-verdrag Handicap goed begrepen, want in artikel $8 \mathrm{VN}$-verdrag Handicap is een expliciete verplichting voor de Staat opgenomen om maatregelen te nemen:

a. teneinde binnen de gehele maatschappij, waaronder ook op gezinsniveau, de bewustwording te bevorderen ten aanzien van personen met een handicap, en de eerbiediging van de rechten en

Mr. D.C. (Dick) Houtzager is Senior Programmamanager bij ZonMw en hoofdredacteur van Handicap \& Recht. waardigheid van personen met een handicap te stimuleren;

b. om op alle terreinen van het leven stigmatisering, vooroordelen en schadelijke praktijken ten opzichte van personen met een handicap te bestrijden, met inbegrip van die gebaseerd op grond van sekse en leeftijd;

c. om de bewustwording van de capaciteiten en bijdragen van personen met een handicap te bevorderen.

Op meer terreinen lijkt de bewustwording over de noodzaak van inclusie toe te nemen. In een rapport van mei 2019 doet de Gezondheidsraad verslag van een onderzoek naar de relatie van de arts of behandelaar met mensen die niet goed hun eigen beslissingen kunnen nemen. Als een van de uitgangspunten hanteert de Raad artikel 12 VN-verdrag Handicap. Hij zegt dat de autonomie van de betrokkene moet worden gerespecteerd en, wanneer mogelijk, de vertegenwoordiger een stap terug moet doen. Aanbevelingen in het rapport gaan vooral over het scheppen van duidelijkheid over de rol van de vertegenwoordiger. Een aanzet daartoe zou het opstellen van een Handreiking met handelingsperspectieven voor zorgverleners en anderen kunnen zijn. ${ }^{1}$

Op het wetgevingsfront is na een lange voorbereiding de invoering van de Wet zorg en dwang (Wzd)en de Wet verplichte geestelijke gezondheidszorg (Wvggz) gepland. De wetten worden op 1 januari 2020 van kracht. Nu de noodzakelijke opvolgers van de Wet Bopz worden ingevoerd, komt wel de vraag aan de orde of de manier waarop gedwongen zorg mogelijk wordt gemaakt, voldoet aan mensenrechtelijke normen. Daarbij is specifiek van belang artikel $14 \mathrm{VN}$-verdrag Handicap. In dat artikel komt de bepaling voor 'dat het bestaan van een handicap in geen geval vrijheidsontne-

1. Goede vertegenwoordiging, Den Haag: Gezondheidsraad, 2019; publicatienr. 2019/08. 
ming rechtvaardigt'. Het kabinet stelt zich op het standpunt dat in gevallen van ernstig nadeel, het toepassen van dwang niet in strijd is met deze normen. Bovendien verwijst het kabinet met betrekking tot artikel $14 \mathrm{VN}$ verdrag Handicap op de interpretatieve verklaring die bij de ratificatie werd afgelegd. In die verklaring legt de regering het artikel zo uit dat gedwongen zorg onder strenge voorwaarden is toegestaan. Vooralsnog zal de sector moeten wennen aan de toepassing van de wet. Dat er jurisprudentie komt waarin de vraag naar compatibiliteit met verdragen aan bod komt, is te verwachten. Ten aanzien van de werkgelegenheid blijft de arbeidsdeelname van mensen met een beperking problematisch. In een recent onderzoek van het $\mathrm{SCP}^{2}$ staat:

'Twee derde van de werkgevers voelt zich (enigszins) verantwoordelijk om mensen met een arbeidsbeperking in dienst te nemen. Dat werkgevers zich verantwoordelijk voelen, wil nog niet zeggen dat ze ook plekken creëren voor mensen met een arbeidsbeperking. Het aandeel werkgevers dat denkt in de komende 2 jaar (meer) mensen uit deze doelgroep in dienst te nemen is beperkt: $11 \%$.'

Er zijn, ook in het kader van de Wet banenafspraak en quotum arbeidsbeperkten, de nodige initiatieven om meer inclusie te bereiken. Werkgeversorganisaties steunen De Normaalste Zaak, een MKB-netwerk dat ondernemers helpt bij het matchen van werknemers met een beperking met werkgevers. Op de regionale arbeidsmarkt werken de Vereniging Nederlandse Gemeenten, Divosa, het UWV en Cedris, de landelijke vereniging voor een inclusieve arbeidsmarkt, samen om de dienstverlening aan werkgevers en werknemers te verbeteren. Vanuit het kabinet is staatssecretaris Tamara van Ark van SZW een 'Breed Offensief' gestart. Zij wil dat meer werkgevers mensen met een beperking in dienst nemen. Ook moet het voor meer mensen met een beperking aantrekkelijk worden om te gaan werken. De voorstellen worden momenteel uitgewerkt en de uitvoering zal naar verwachting in 2020 beginnen.

Bewustwording is er op dit terrein zeker. Gelet op de wat sombere constatering van het SCP, is het wel de vraag of de plannen en inspanningen vrucht gaan afwerpen.

In dit nummer van Handicap $\leftleftarrows$ Recht twee bijzondere onderwerpen. Bij de ratificatie van het VN-verdrag Handicap heeft Nederland het facultatief protocol bij het verdrag niet getekend. In dat protocol is een individueel klachtrecht opgenomen. Op basis van dat protocol kan het toezichthoudend comité van de Verenigde Naties een specifieke zaak onderzoeken en beoordelen of het verdrag geschonden is. Bij andere mensenrechtenverdragen, zoals het Rassendiscriminatieverdrag (CERD) en het Vrouwenverdrag (CEDAW), is dat protocol wel ondertekend en in werking getreden. AnneRose Stolk geeft in haar artikel uitleg over de achter- grond van het protocol en over de terughoudendheid van de Nederlandse regering met de ondertekening.

In hun bijdrage gaan Sander Schuitemaker en Martine Goeman van Defence for Children in op een onderzoek naar de situatie van kinderen met beperking in de asielprocedure. Voor veel kinderen in asielopvang is in de praktijk weinig ondersteuning bij hun handicap beschikbaar. De auteurs toetsen deze praktijk aan het Kinderrechtenverdrag en het VN-verdrag Handicap.

In de rubriek Jurisprudentie volgt de bespreking van een arrest van Hof Amsterdam. De zaak gaat over de weigering van een Vereniging van Eigenaars om toestemming te geven voor het stallen van een scootmobiel in een ruimte van een appartementengebouw. In het commentaar bij de uitspraak komt de vraag aan bod of de civielrechtelijke benadering die het hof toepast, de meest geschikte benaderingswijze voor een dergelijke zaak is.

Tot slot een mededeling van de redactie. Tot onze vreugde is Jiska Stad-Ogier, student notarieel recht en medeoprichter van Wij Staan Op, tot de redactie toegetreden. We wensen haar veel plezier en succes. 